Academic City University College - Accra Ghana

Society for Multidisciplinary \& Advanced Research Techniques (SMART) Africa

Tony Blair Institute for Global Change

FAIR Forward - Artificial Intelligence for All - Deutsche Gesellschaft für Internationale Zusammenarbeit (GIZ) GmbH

Accra Bespoke Multidisciplinary Innovations Conference (ABMIC)

\title{
African Divinatory Systems and The Modern Debate On African Philosophy
}

Adegbindin Omotade, Ph.D

Department of Philosophy

University of Ibadan

Ibadan, Nigeria.

E-mail: tadegbindin@yahoo.com

Phone Number: +2348024947552 


\title{
African Divinatory Systems and The Modern Debate On African Philosophy
}

\author{
Adegbindin Omotade, Ph.D
}

\begin{abstract}
In classical literature, we read of a serious debate surrounding the possibility of divination. More specifically, we read of Cicero's alleged denunciation of divination as superstitio, leading to divergent reactions and also urging the need to provide justification for the possibility of divination. Although it is often said that Cicero's de Divinatione has suffered different interpretations since his time to date, the suspicion still remains that, perhaps, the text itself assumes that science-and, by extension, the imposition of certain cognitive modes on othersis the hēgēmon in matters concerning the state and human existence; the oracular cannot disclose the true nature of the universe. Cicero's position is no doubt a compelling reflection of the sharp differentiation between European and African thought that has endured as an issue that is mostly discussed in African philosophy. For the African, the issue of debate on the possibility of divination does not arise: as a matter of fact, divination, for him, serves as a veritable means through which he can understand the configurations of the entire universe and his place in it. Thus, this paper invariably attempts a deconstruction of the myth of writing that is mostly associated to the constitution of science or/and philosophy and shows that African divinatory systems and their related mythical or religious conceptions represent a legitimization of the body of wisdom found in orality.
\end{abstract}

Keywords: Africa, Divinatory Systems, Modern Debate, African Philosophy

\section{INTRODUCTION}

As a product of necessity, ethnophilosophy is seen as a critical reflection on the questions surrounding the admission of the existence of African philosophy. In light of this, it is a counterreflection on the denial of the capability of Africans to develop a set of thoughts that passes for philosophy and, therefore, can be glossed as a system developed only as a reaction to Western denigration of the intellectual capabilities of the African. One of the main concerns of the notable champions ${ }^{1}$ of this trend is "to debunk the ethnocentric assertion made by first generation of European Africanists that African people are incapable of rational and rigorous reflection and analysis." 2 As a conscious exemplification of the ideals of African belief system that predates Africa's contact with the West, it is a response to the denial of African philosophy or a representation of a body of thoughts that illuminates the connection between philosophy and culture.

\footnotetext{
${ }^{1}$ These include J.S. Mbiti, Bolaji Idowu, Robin Horton, Alexis Kagame

2 Kolawole A. Owolabi, “African Philosophy: Retrospect and Prospect," Owolabi, K.A. Ed. Issues and Problems in Philosophy (Ibadan: GROVACS Network, 2000), p. 13.
} 
This highlights the fact that philosophy is best understood within its cultural context, thereby adding more currency to the view that all humans have a unique quality which is "the ability for self-reflection and rational thought governed essentially by certain principles of reasoning." 3 Godwin Sogolo explains further that:

this unique human quality, like others, has its own local colour and peculiar mode of manifestation, all depending on the contingencies of the intervening culture. The point to be emphasised is that the structure of the human mind is essentially alike and men reason alike in all cultures. There are, however, cultural factors that condition the forms in which this reasoning is manifested. Its peculiar form in any culture cannot, therefore, be seen as a deficiency or worse still taken as a mark of irrationality. 4

The import of Sogolo's view is consistent with Polycarp Ikuenobe's assertion that ethnophilosophy "is a legitimate philosophy, because it can help us to examine, clarify, articulate, and constrain the nature of cultural norms, practices, paradigms, and procedures of inquiry that can yield reasonable beliefs or knowledge." ${ }^{5}$ As we shall see in what follow, divination in Africa "functions within the context of a larger social system" 6 and, as a strand of ethnophilosophy, "involves a contextual view of reasonableness that does not specify truth as a necessary condition" 7

\section{THE IDEA OF DIVINATION}

Indeed, for the African, "the cosmos does not constitute a fixed, cold and mute world. On the contrary, it is a world charged with meanings and laden with messages, a world which "speaks"' 8

Dominique Zahan adds more aptly.

Thus man finds in his surroundings a partner with which he can enter into communication, with which he must in fact maintain an almost constant dialogue if he wants to be informed about himself. This is because the macrocosm contains $n$ itself all the potentialities of the microcosm which is man. In this sense the world possesses an absolute value. Consequently, to know oneself it is necessary for now to know the messages which the universe continuously sends. It is through these messages that one can interpret one's own destiny. ${ }^{9}$

\footnotetext{
${ }^{3}$ Godwin Sogolo, Foundations of African Philosophy: A Definitive Analysis of Conceptual Issues in African Thought (Ibadan: University of Ibadan Press, 1993), p. xv.

4 Ibid., pp. xv-xvi

5Polycarp Ikuenobe, “Logical Positivism, Analytic Method, and Criticisms of Ethnophilosophy," Metaphilosophy Vol. 35, No. 4 (2004), p. 491.

6 M.W. Payne, "Akiwowo, Orature and Divination: Approaches to the Construction of an Emic Sociological Paradigm of Society," Sociological Analysis Vol. 53, No. 2 (1992), p. 183.

7 Ikuenobe, "Logical Positivism," p. 493. This, according to Ikuenobe, implies that "a belief will be one that aperson accepts as having a high probability of being true to the person's conceptual scheme, to his or her sociocultural context of norms and practices, and to the available evidence in his or her community."

8 Dominique Zahan, The religion, Spirituality, and Thought of Traditional Africa, Translated by Kate E. Martin and Lawrence M. Martin (Chicago: The University of Chicago Press, 1979), 81.

9 Ibid.
} 
The above shows therefore that "the messages which the universe continuously sends" are held to be both authoritative and deserving interpretation as this also stipulates a crosscommunication. The idea of cross-communication underscores a possible link between mortal individuals and the cosmic order which, mostly held as a divinely created order, is eternally in the hands of the gods, angels, and so on. Consequently, it is thought that humans have always wanted to penetrate the cosmic order in order to have "answers to questions beyond the range of ordinary human understanding." 10 For they are aware that the gods or higher powers communicate their plans, intentions and decisions-or, better distilled as divine secrets-as they relate to human existence "by means of perceptible patterns of phenomena," 11 humans employ a plethora of methods to know the position of the gods most especially on matters of life-crises.

With the help of certain gifted individuals, referred to as diviners, divine secrets are deciphered and revealed to mortal men, leaving them with choices to make-whether to heed certain warning of the gods and observe some rituals or to see the cosmic order as a matter of chance. In light of the foregoing, divination is defined as "a practice, usually involving the use of supernatural means which seeks to reveal or discover hidden knowledge or occult realities." 12 In other words, it is "a process for obtaining information which is (typically) unavailable by ordinary means, that is, which cannot be gotten by the usual techniques of indigenous practical epistemology, such as seeing, hearing, being told by another person-the commonplace categories of evidential coding systems." 13 For John Middleton, it is "the attempt to discover events that do or will affect human begins for good or evil, but that are beyond their control and are believed to have a supernatural, mystical, or other-than-human cause."14

In this way, divination is understood as "a stepping stone between pondering a problem and acting to solve it, whether by ritual action or otherwise. It is a means of clarifying thought, of answering recondite questions." 15

\footnotetext{
10 Barbara Tedlock, “Divination as a Way of Knowing: Embodiment, Visualisation, Narrative, and Interpretation," Folklore Vol. 112, No. 2 (2001), p. 189.

${ }^{11}$ Dephna Arbel, “The Highest of all Tapsarim? 3 Enoch and Divinatory Traditions,” Jewish Studies Quarterly Vol. 15, No. 4 (2008), p. 296.

12 Omotade Adegbindin, "Divinatory Systems," in Culture and Customs of the Yoruba, edited by Toyin Falola and Akintunde Akinyemi (Austin: Pan-African University Press, 2017), 363.

13 John W. Du Bois, "Meaning without Intention: Lessons from Divination," in Responsibility and Evidence in Oral Discourse, edited by J.H. Hill and J.T. Irvine (Cambridge: Cambridge University Press, 1992), p. 54.

14 John Middleton, "Divination," in The Encyclopedia Americana, International Edition, 9 (Danbury: Grolier Incorporated, 1997), p. 196.

15 David Zeitlyn, "Spiders in and out of Court: Styles of Spider Divination in Their Sociological Contexts," Africa: Journal of the International African Institute Vol. 63, No. 2 (1993), p. 225.
} 
According to Anne Marie Kitz, divination presupposes that "all divine action causes material reaction," 16 implying that the deities, gods, angels, and so on, "are the activating directors of a material world in which individual components can function as their agents." 17 Kitz provides the basis for recognising a divine activity further, namely, the extraordinary quality of the event or activity, its recurrence and its ritualistic mode. She breaks down the first feature and explains that an activity or event divine if it goes beyond the "anticipated behaviours and/or exhibits great power."18

In this sense, she explains:

Such natural phenomena as eclipses, comets, earthquakes, floods, and storms would be seen as divine activities. Likewise, the effects that these occurrences generated (the material manipulation), including lightning strikes, erosion, and catastrophic flooding, would naturally be understood as signs that required further explanation. ${ }^{19}$

The feature of recurrence, according to Kitz, stipulates that a divine activity could be understood through signs-for example, dreams-that are repetitive. In other words, signs that do recur often attract the need for divinatory confirmation and, therefore, in the words of Kitz, "the doubling or tripling of divinatory procedures around the same issue served to establish the degree of inevitability of what was predicted." 20 She adds that "the inability to find a negation, whether solicited or unsolicited, to a particularly strong sign would also indicate the inescapable completion of whatever that sign portended." 21 With illuminating illustration, Kitz offers ritual as a means of identifying a divine activity. Since every human culture has the idea of a plethora of deities, rituals often help to identify the deity that is involved in a particular divine activity and know the dimensions of the deity's involvement or disposition.

\section{More succinctly:}

... rituals were a tool that not only established which deity was acting and how that deity was to reply (birds, stars, lightning) but also enabled the diviner to identify the heavenly action that was sent in reply to his or her inquiry. To press the argument further, rituals could also enable diviners to distinguish an otherwise ordinary sight as a sign sent in reply to a ritually pored question. Therefore, when an omen of extraordinary character was not available, rituals helped maintain an ongoing dialogue between the heavenly and earthy realms. ${ }^{22}$

\footnotetext{
${ }^{16}$ Anne Marie Kitz, “Prophesy as Divination,” The Catholic Biblical Quarterly Vol. 65, No. 1 (2003), p. 24.

17 Ibid.

18 Ibid., p. 25.

$19 \mathrm{Ibid}$.

$20 \mathrm{lbid}$.

${ }^{21}$ Ibid.

22 Ibid., p. 27.
} 
In his dialgoue Phaedrus, Plato distinguishes between mantike or mantic trance and oionistic. The first is the type of divination "that comes through divine madness and inspiration." 23 The word mantike is derived from mania or furor in Latin and it connotes "madness", "insanity" or, when tied to the art of divination, "divine possession". This type of divination is also classified as natural as "it requires no interpretive skill on the part of the diviner," 24 or, following David Zeitlyn, "inspirational" or "revelatory", a type of divination "in which the diviner has direct contact with a deity (often via a form of possession)." 25 Mantic trance is therefore an altered state of consciousness in which a deity or spirits are believed to influence the process or outcome of divination. ${ }^{26}$

The second type of divination, oionistic, is a Greek term that connotes "enquiry". It is variously referred to as the "technical", 27 "artificial",28 "mechanical". 29 As technike, this type of divination requires that the interpretive exercises of the technical practitioners-that is, their skills or techniques-are used to decode or interpret signs to produce answers. In Phaedrus, this type of divination is regarded as that which "is undertaken by sane men through birds and other signs." 30 That is, "the inductive art of the uninspired and sane who inquire purely from human reasoning into the future by observing birds flights and other omens." 31 Although Plato does not disregard this type of divination completely, he however sees the inspirational as superior or "more honourable because it is inspired," 32 proceeding from a god, while the technical is undertaken by mortal individuals.

\section{AFRICAN DIVINERS AND DIVINATORY SYSTEMS}

Across different cultures and in several parts of the world, divination is characterized by material manipulation by a deity, a sign and, lastly, the interpretation of the sign. Taking the first, a deity communicates his/her disposition to humans usually by manipulating any element-animate or inanimate-in the physical world, leaving humans with the problem of deciphering or analyzing, through divination, a "divine activity as manifested in its effect on the physical universe." 33

\footnotetext{
${ }^{23}$ Kathryn A. Morgan, “The Voice of Authority: Divination and Plato’s “Phaedo”," The Classical Quarterly Vol. 60, No. 1 (2010), p. 68.

24 R.J. Hankinson, "Stoicism, Science and Divination," Apeiron: A Journal for Ancient Philosophy and Science Vol. 21, No. 2 (1988), p. 127.

${ }^{25}$ Zeitlyn, “Spiders in and out of Court: Styles of Spider Divination in Their Sociological Contexts," p. 226.

${ }^{26}$ Alan M. Greaves, "Divination at Archaic Branchidai-Didyma: A Critical Review," Hesperia: The Journal of the American School of Classical Studies at Athens Vol. 81, No. 2 (2012), p. 181.

${ }^{27}$ See Tedlock, "Divination as a Way of Knowing: Embodiment, Visualisation, Narrative, and Interpretation," 190; Hankinson, "Stoicism, Science and Divination," p. 127.

28 See Hankinson, “Stoicism, Science and Divination," p. 127.

${ }^{29}$ See Zeitlyn, “Spiders in and out of Court: Styles of Spider Divination in Their Sociological Contexts," p. 226.

30 Morgan, “The Voice of Authority: Divination and Plato's “Phaedo”," p. 68.

${ }^{31}$ Tedlock, “Divination as a Way of Knowing: Embodiment, Visualisation, Narrative, and Interpretation,” p. 190.

32 Morgan, “The Voice of Authority: Divination and Plato's “Phaedo"," p. 68.

${ }^{33}$ Kitz, “Prophesy as Divination,” p. 28.
} 
Divination is in this light a human response to the material manipulation through which deities express their divine sentiments. ${ }^{34}$

Kitz explains that a system of divination also is characterized by a sign or an omen, regarded as "something that can be identified as representing the disposition of a deity." 35

She explains that:

...the material manipulated by the deities obviously does not constitute the sign. Thus, the liver in a sacrificial animal is not the sign; rather, the heavenly inscribed marks on the liver are the sign. The birds themselves are not the sign, but it is their divinely prompted calls and/or movements from right to left or left to right, and so on. Therefore, a human being is not necessarily the sign, but it is the heavenly generated dream, vision, word, or divinely orchestrated deed that actually constitutes a sign. ${ }^{36}$

With the above in mind, divination is therefore characterized with the need to interpret the signs and this is associated with the activity of those referred to as diviners. ${ }^{37}$ Hence, diviners are "those individuals who possess either the innate ability or have acquired the necessary intensive, protracted education and training to peer into otherwise hidden events." 38

M. W. Payne identifies two broad categories of diviners in Africa, namely, "those individuals who themselves are spirit mediums" and "those who divine through the manipulation and interpretation of material objects." 39 According to Payne, the first category has to do with those individuals who, as humans with corporeal existence, still "establish a direct connection with the spirit world." 40

Payne adds that:

This category of diviners includes those mediums who, generally within a ritual context, are possessed by a spirit, who then speaks through the medium. Alternately, diviners in this category may actually see, hear, feel or intuit the spiritual world and are not possessed in order to relay a message to beings within the corporeal world. ${ }^{41}$

\footnotetext{
34 Ibid., pp. 27-28.

35 Ibid., p. 32.

36 Ibid., p. 33.

37 Ibid., p. 34.

38 Payne, "Akiwowo, Orature and Divination: Approaches to the Construction of an Emic Sociological Paradigm of Society," p. 181.

39 Ibid.

40 Ibid.

41 lbid.
} 
Diviners who belong to the second category are actually those trained individuals whose depth of training, retentive memory and intellectual acumen are harnessed in the course of interpreting the manipulated material objects such as, in Payne's words, "Water, mirrors, palm nuts, kolanuts, pebbles or stones, seed shells, cowrie shells, groundnut shells, mats, leaves, bones, roots beads, the Koran, and sand." 42 Payne offers a subset of the two categories identified above which includes "mediums who manipulate physical objects which, to some degree, interpretation." $43 \mathrm{He}$ contends that knowledge of divination in this subset "is seldom, if ever, codified to the point where standard patterns can be recognized and taught to prospective apprentices." 44

Incidentally, however, the two previous categories of diviners are most consequential to our discussing of African divinatory systems; although Africa can boast of a cluster of divinatory systems, these systems can be grouped under two major types, the mediumistic and the manipulative or interpretive. We must note that these two categories or labels are not distinctly different from the ones drawn from classical literature, the inspirational and the technical. To avoid undue duplication of divinatory ideas or performance and for dearth of space, I limit myself to the citing of two or three instances for each of the two types of divinatory systems. These are drawn mainly from enlightening documentation by earlier scholars.

\section{MEDIUMISTIC DIVINATORY SYSTEMS}

Although the Sukuma of Tanzania employ divination "in cases of casual fortune seeking," 45 they and the Fipa of Tanzania undertake divination mostly to reveal the occult cause of sickness. The two Tanzanian communities recognize the pivotal role of the ancestral spirits in divination. Among the Sukuma, for instance, a diviner is reputed to be someone who has been afflicted by an ancestral spirit and is therefore summoned by the ancestor involved "to carry on his or her divining tradition." 46 Referred to as ng'hambo, this type of divination features the use of an inala (a euphorbia twig), a gourd rattle and a winnowing basket. ${ }^{47}$

Koen Stroeken explains that "Fresh euphorbia twigs secrete a milky substance to which the subject has transmitted his or her saliva so that the medium can divine it." 48 For the scepticism that certain forces can intervene to corrupt the outcome of an oracle, a Sukuma client, especially, does not rely heavily on the mediumistic pronouncement of a diviner.

Thus:

\footnotetext{
$42 \mathrm{Ibid}$. Payne notes however that, "In Africa, the process of diffusion and reinterpretation were at work and have prompted divination with certain objects, originating outside of Africa, such as mirrors, cowrie shells, and the Koran."

43 Ibid., p. 182.

44 Ibid.

45 Koen Stroeken, "Believed Belief: Science/Religion versus Sukuma Magic," Social Analysis: The International Journal of Social and Cultural Practice Vol. 52, No. 1 (2008), p. 146.

46 Ibid.

47 Ibid.

48 Ibid.
} 
Clients go to remote villages to find diviners without inside information and double-check their conclusions with yet other diviners, supposedly unaware of each other's diagnosis. New techniques to purify oracular objects from occult influence are introduced, such as their submersion in water or their passage through tilled mounds of earth. 49

Among the Fipa, the aka miyaao are the most revered since it is believed that they had been chosen by the gods. ${ }^{50}$ As spirit-mediums, these diviners, unlike non-specialists or "possessors and practitioners of esoteric magico-medical lore and expertise," 51 are employed "in the case of individual, private sickness and on occasions of general public distress, such as during epidemics and famines." ${ }^{2}$ Roy Willis describes the method of divination involving the aka miyaao thus:

The medium uses a long string of white beads (ukasi) and some small gourds, in each of which a grain, usually of maize, is put...If the medium agrees to attempt divination, he goes and puts the beads round his neck and takes up the gourds. He then goes to a suitable spot and shakes the gourds, calling on the spirits (imyaao). He begins to tremble violently. The audience remove his beads and take away the gourds. He then begins to pronounce. 53

Imyaao are a multitude of spirits or gods who are ranked next to Indeesa, the creator of the world. ${ }^{54}$ In deferring to ancestral spirits, Fipa divination puts much premium on two classes of ancestral spirits, namely, the imisimu and the ifiiswa. Willis explains that the former, who are benevolent spirits, cause misfortune only when their descendants fail to make offerings to them, while the latter, who are malevolent spirits, "harm their descendants without justification." 55 Through divination, therefore, a man's sickness or misfortune is traced to either of these two mystical agencies.

The Gisu, a Bantu speaking people of Uganda, demonstrate a strong connection between ancestral power and divination in their system of divination. Gisu diviners, referred to as bafumu, claim to have "direct communication with the ancestral world and access also to distinctive forms of counteraction." 56

\footnotetext{
49 Ibid., p. 151.

50 Roy G. Willis, “Changes in Mystical Concepts and Practices among the Fipa,” Ethnology Vol. 7, No. 2 (1968), p. 155.

51 Ibid., p. 142.

52 Ibid.

$53 \mathrm{lbid}$.

54 Ibid., p. 140.

55 Ibid., p. 141.

56 Suzette Heald, "Divinatory Failure: The Religious and Social Role of Gisu Diviners," Africa: Journal of the International African Institute Vol. 61, No. 3 (1991), p. 301.
} 
According to Suzette, Heald:

Diviners ... may attempt to interpret the wishes of the ancestral ghosts (bamakombe), or the ancestral spirits (basambwa) and their associated powers (kimisambwa), while some also claim powers to counteract sorcery. Of these latter, some are recognized sorcery seekers, known as balyuli, who 'smell out' sorcery substances buried along the paths or in the compound or hidden in the thatch of houses. Others are known to practice more direct forms of vengeance sorcery. ${ }^{57}$

It must be added here that Gisu divination is not predictive but revelatory because divination is undertaken only to reveal "the cause of a misfortune which has already occurred." 58

The Yaka of the Democratic Republic of Congo employ different divination processes like the adhering horn oracle, rubbing oracle, ordeal by fire or poison and ngoombu weefwa. ${ }^{59}$ Filip de Boeck and Rene Devisch seem to suggest that ngoombu weefwa-perhaps, because of its tie to the ngoombu cult of divination-is given great credence among the Yaka. 60 Yaka divination cannot be displaced from both patrilineal descent and matrilineal filiation and this is why, as René Devisch puts it, "The concern of divination among the Yaka must be placed in the context of kinship and particularly in that of uterine relations."61 This means that Yaka divination, following Devisch again, "implies an etiological grid in relation basically to uterine lifetransmission." 62 Arthur Bourgeois notes that ngoombu divination is indifferent to age or sex and, therefore, the diviners "can be male or female and some may be hardly out of their teens." 63

During initiation, an initiate undergoes a ritual affliction which, for the Yaka, indicates that the initiate is called to be a diviner and also suggests why ngoombu weefwa is "concerned with hereditary curses and curing". Complementing the path of becoming a Yaka mediumistic diviner, Bourgeois lists the features of an initiation: “...seizure by a persistent illness, ...trance occurrence with bizarre behavior, ...testing for extra-sensory knowledge, and ...formal training under ngoombu practitioners." 64

\footnotetext{
57 Ibid.

58 David M. Anderson and Douglas H. Johnson, "Diviners, Seers and Spirits in Eastern Africa: Towards an Historical Anthropology," Africa: Journal of the International African Institute Vol. 61, No. 3 (1991), p. 294.

59 Arthur Bourgeois, “Mukoku Ngoombu: Yaka Divination Paraphernalia,” African Arts Vol. 16, No. 3 (1983), p. 56.

60 Fillip de Boeck and Rene Devisch, "Ndembu, Luunda and Yaka Divination Compared: From Representation and Social engineering to Embodiment and Worldmaking," Journal of Religion in Africa Vol. 24, No. 2 (1994), p. 120.

61 René Devisch, “Mediumistic Divination among the Northern Yaka of Zaire," in African Divination Systems, edited by Philip M. Peek (Bloomington: Indiana University Press, 1991), p. 112.

$62 \mathrm{lbid}$.

63 Bourgeois, “Mukoku Ngoombu: Yaka Divination Paraphernalia," p. 56.

64 Ibid.
} 
He adds:

Most extraordinary is the diagnostic ngoombu trance during which the victim leaps onto the roof of a village cabin and scratches apart the thatched roof amid high-pitched cries ..., all the while the head and body twitching and jerking like a chicken's. During this behavior the person reveals the name of the deceased diviner forebear responsible for the possession. 65

The paranormal behavior is the proof of an initiate's calling.

\section{INTERPRETIVE DIVINATORY SYSTEMS}

The Sisala occupy the savannah woodland of northern Ghana and their social organization is based on patrilineal descent. With regard to divination, the Sisala see a connection between religious rituals and divination, whereby there is a strong emphasis on the role or involvement of the ancestors in the process of divination. For the Sisala, therefore, divination forms a central part of their religious behavior which is usually defined in terms of a "ritual behavior in response to some concrete affliction." 66 This highlights the fact that divination is mostly carried out among the Sisala to discern the cause of an affliction through which the ancestors are believed to communicate to the living.

An affliction then suggests mostly that an ancestor is offended and, therefore, seeks to communicate the ritual remedy to the client through a diviner (vugura), "the human agents of the ancestors." 67 In light of the foregoing, Eugene Mendonsa defines the Sisala divinatory process as “...sequence of events beginning with the perception of affliction which leads to the consultation of a diviner and which further leads to a retributive ritual act, usually sacrifice, which is thought to appease the offended ancestor or other occult entity responsible for the affliction."68

Closely linked to divination among the Sisala are the concepts of time and fate. In view of the former, the Sisala distinguish between fafa and lele and this relates directly to the ritual process whereby the Sisala consult a diviner after an affliction and proceed to sacrifice on an ancestral shrine." 69 As a timeless reality, fafa is the occult abode of God, spirits and ancestors. It is, according to Mendonsa, "the realm of the mythological events about the beginning of man, the exploits of culture heroes and remembered ancestors.

\footnotetext{
$65 \mathrm{Ibid}$.

66 Eugene L. Mendonsa, "Etiology and Divination among the Sisala of Northern Ghana," Journal of Religion in Africa Vol. 9, No. 1 (1978), p. 36.

67 Ibid., p. 35.

68 Ibid., p. 36.

69 Ibid., p. 38.
} 
Occult causation originates in this state and the only way to determine this causation is by consulting a diviner who has the power to contact the ancestors." 70 It must be noted here that the idea of a "diviner's power", as construed by Mendonsa, may give the impression that this divinatory system is mediumistic; a careful reading of the system shows however that it is manipulative or interpretive as the diviner-with a thorough involvement of the client-relies mostly on the use of certain apparatus in determining the cause of an affliction. In other words, the divinatory process may not hold if, for instance, the diviner fails to use vugura dang (the divining wand), vugura kpasing (the code-objects) and tayangba (the two metal discs). ${ }^{71}$

The use of these apparatus or paraphernalia of divination shows further that both the diviner and the client are involved in the process of divination. As a matter of fact, to arrive at the cause of an affliction and determine the solution to it, the client can be said to be more involved than the diviner in the divination process. For instance, vugura kpasing helps the clients to distill a series of binary questions-in form of a "yes-no"-to either a "yes or no", thereby determining "the ancestor responsible for his illness, the exact shrine which must be sacrificed on, and the kind of animal required in the sacrifice." 72 In this way Mendonsa is right to point out that the function of the Sisala diviner "is a passive one." 73

The concept of fate among the Sisala evokes the perennial problem of God in traditional African thought. Recall that, in most Eurocentric writings, God in Africa has been variously described as Deo Remotus, Deo absconditus, presenting the derogatory idea that Africans do not have an idea of a Supreme Being. This is also the basis for such ascriptions as polytheism, polydemonism, pantheism, in respect of African religious persuasions. Of course, the Sisala acknowledge that the ancestors can be appeased in matters of health crises to get positive results; they also know that some afflictions cannot be subdued through divination or by appeasing the ancestors. In short, the Sisala are aware that "there is a possibility of control over ancestral anger, there is no control over the will of God." 74

Among the Yorùbá of southwestern Nigeria, Ifá is consulted in virtually all matters concerning human existence, not necessarily during private or public crises. Ifá can be used interchangeably to refer to both the system of divination and Ò $\square$ rúnmilà, the Yorùbá deity of wisdom. Interestingly, the objects of divination among the Sisala draw our attention to the objects of divination used by Ifá diviners or babalawo. Like vugura dang of the Sisala, ibò in Ifá divination is a pair of cowry shells strung together and a piece of animal bone. To aid and expedite the process Ifá divination, the client is expected to hide away the cowry shells and the bone each in a palm. This way, the client is said to d' ibò (literally, to vote) which involves "the use of specific alternatives of "yes" and "no" by the Ifá priest to arrive at the answer to the client's questions which are posed in terms of two statements, the first affirmative, the second negative." 75

\footnotetext{
70 Ibid.

71 Ibid., p. 34.

72 Ibid., p. 35.

73 Ibid.

74 Ibid., p. 39.

${ }^{75}$ See William Bascom, Ifa Divination: Communication Between Gods and Men in West Africa

(Bloomington: Indiana University Press, 1969), p. 53; Olufemi Taiwo, "Ifa: An Account of a Divination System and Some Concluding Epistemological Questions," in A Companion to African Philosophy, edited by Kwasi wiredu ( Oxford: Blackwell Publishing Ltd, 2004), pp. 304 - 312; Omotade Adegbindin, Ifá in Yoruba Thought System (Durham: Carolina Academic Press, 2004), p. 64. Olufemi Taiwo,
} 
In the case of Ifá divination, however, the Yorùbá diviner, unlike his Sisala counterpart, is more involved in the process than the client. The Yorùbá diviner may need to manipulate the divining chain (òpẹlẹ) several times before he determines the source of the client's problem and the sacrifice involved. Again the use of ibò, two clients is naturally not in doubt of the outcome of the divination and the suspicion that the Yorùbá diviner is "the author of the figure that emerges after the cast of the opẹlè "is thereby removed." 76 Another important difference to note has to do with the types of divine intervention involved in the two divinatory methods. While the Sisala lays so much emphasis on the intervention of the ancestors during divination, the Yorùbá metonymically attribute theirs to Ifá or ọ $\square$ rúnmilà who occupies a primordial status far above that of an ancestor.

The few divinatory systems cited above naturally aid a typology for a plentiful other divinatory systems across Africa: nggam du (spider divination) among the Cameroonian Mambila77; fourtablet divination in Southern Africa ${ }^{78}$; maraboutic and cowrie divination performances in Senegambia79; sikidy divination in Madagascar80, and many more. There are, however, some African divinatory processes and performances that may not yield to easy classification under either the mediumistic or the interpretive.

A good example is found among the Nyoro of Bunyoro, Uganda. According to John Beattie, the Nyoro have three modes of divination, namely, the mechanical modes of divination, divination by augury and divination by reference to spiritual powers. Beattie ${ }^{81}$ explains that the first has to do with "the manipulation of material objects and the operation of what we should call "chance"." The second is "the observation, in specially prepared conditions, of the behavior or some other aspect of animals," while the third, among the Nyoro, is "divination by reference to "spiritual" powers or forces with quasi-human attributes, sometimes mediated through techniques of spirit mediumship, sometimes involving the use of ventriloquy." Except the last, the other two still have their different kinds.

\footnotetext{
"Kín N'Ifá Wí?: Philosophical Issues in Ifá Divination," in Ifá Divination, Knowledge, Power, and Performance, edited by Jacob K. Olupona and Rowland Abiodun (Bloomington: Indiana University Press, 2016), pp. 100 -116.

${ }^{76}$ Adegbindin, Ifa, p. 59.

77 See David Zeitlyn, “Mambila Divination,” The Cambridge Journal of Anthropology Vol. 12, No. 1 (1987), pp. $20-51$.

78 See Wim van Binsbergen, "Regional and Historical Connections of Four-Tablet Divination in Southern Africa," Journal of Religion in Africa Vol. 26, No. 1 (1996), pp. 2-29.

79 See Knut Graw, “Locating Nganiyo: Divination as Intentional Space," Journal of Religion in Africa Vol. 36, No. 1 (2006), pp. 78119; Knut Graw, "Beyond Expertise: Reflections on Specialist Agency and the Autonomy of the Divinatory Ritual Process," Africa: Journal of the International African Institute Vol. 79, No. 1 (2009), pp. 92-109.

80 See Pierre Vérin and Narivelo Rajaonarimanana, "Divination in Madagascar: The Antemoro Case and the Diffusion of Divination," in African Divination Systems, edited by Philip M. Peek (Bloomington: Indiana University Press, 1991), pp. 53-68.
}

${ }^{81}$ John Beattie, "Divination in Bunyoro, Uganda," Sociologus Vol. 14, No. 1 (1964), pp. 4462. 


\section{AFRICAN PHILOSOPHY AND AFRICAN DIVINATORY SYSTEMS}

African philosophy faces the crisis of definition because there are varying opinions about its definition. One, it is defined as the logic of oral tradition, whereby it connotes "the understanding, attitude of mind, logic and perception behind the manner in which African peoples think, act or speak in different situations of life." 82 Two, it is seen as the dispute between the traditionalists and the modernists. In this sense, it is a philosophical reflection on and analysis of African conceptual systems undertaken by the two camps. ${ }^{83}$ The traditionalists argue that authentic African philosophy lies in the past for the sake of the present and therefore can be uncovered by delving into traditonal African past and distancing ourselves from foreign ideas and cultures.

The modernists, on the other hand, put much premium on the need for African development, especially by embracing science and technology, arguing that traditional African society was erroneously guided by authoritarianism, religiosity and superstition. Three, African philosophy is defined as a collection of texts produced by African philosophers, as well as philosophical writings on Africa. Four, understood as the historical source of ethnophilosophy (which is the spine of our discussion here), D.A. Masolo explains:

African philosophy... the historical roots of which are purported by some scholars to be found in the pre-colonial indigenous cultures of African societies, which, according to this view, contained subtle philosophical elements within their respective worldviews. Because it claims that African philosophy is closely interwoven with the practical and verbalized cultural idioms through which it is expressed, this view of African philosophy, launched by the Belgian missionary Placide Tempels in 1944, has come to be designated as ethnophilosophy. ${ }^{84}$

Masolo distinguishes between the negative and positive uses of ethnophilosophy. On the negative side, ethnophilosophy "refers to the ethnographic and non-philosophical methods used by the ethnophilosophers, mainly disciples of Tempels, to recover from African cultural texts propositional beliefs and ideas that they purport to be philosophical." 85 The term is used in the positive sense when it is understood "as a branch of the more general ethnomethodology which is a phenomethodological approach to interpreting everyday cultural expressions as a guide to philosophical research into, and interpretation of, socio-cultural contexts of participants' practices and speech." 86 Coined by Marcien Towa and Paulin Hountondji ethnophilosophy "is based on the presupposition that African philosophy and European philosophy are each of a fundamentally different nature." 87

\footnotetext{
82 John S. Mbiti, African Religions and Philosophy (London: Heinemann, 1969), p. 2.

83 See Olusegun Oladipo, The Idea of African Philosophy, A Critical Study of the Major Orientations in Contemporary African Philosophy, Third Edition (Ibadan: Hope Publications, 2000)

${ }^{84}$ D.A. Masolo, "African philosophy: A Historical Overview," in A Companion to World Philosophies, edited by Eliot Deutsch and Ron Bontekoe (Malden, Mass.: Blackwell, 1999), p. 63.

85 Ibid.

86 Ibid.

${ }^{87}$ Alena Rettová, “The Role of African Languages in African Philosophy,” Rue Descartes Vol. 36 (2002), p. 133.
} 
For Polycarp Ikuenobe, ethnophilosophy is "characterized as the myths, norms, values, beliefs, practices, folktales, proverbs, and other culturally "organized" and accepted ways of how people come to understand and explain their experiences, which they informally talk about and transmit by oral tradition, but without systematic and critical reflection." 88 Of course, academic or professional philosophers have overtly expressed their indignation against "the suggestion that an anonymous corpus of writings that included myths, legends, poetry, song, and proverbs was truly worthy of the title title "philosophy." 89

They maintain that philosophy is "a strict discipline involving criticism, reflexion and logic and done by individual thinkers, who engaged in a discussion together, defend and perfect their theories and contribute to the creation of a written philosophical tradition." 90 It is instructive therefore to bring out the important points in the above rendition of the position of professional philosophers, namely, 'criticism', 'reflexion', 'logic' and 'written philosophical tradition'. Recall that professional philosophers adopt the features of the universalist notion of philosophy ${ }^{91}$ and set their critical barb against ethnophilosophy which, in their opinion, "is not a philosophy ex hypothesi." 92

One of the reasons offered by Anthony Appiah, for instance, in support of this claim is that ethnophilosophy implies a strong cognitive relativism, the view that "what is true is relative to a conceptual scheme and that what is true for one may be false for another." 93 Ikuenobe distils Appiah's argument to show that Appiah, following the logical positivists, believes that there are "scientific methods of determining whether a belief about matters of fact can be objectively true or false."94 By implication, Appiah's position suggests that ethnophilosophy does not accommodate the idea that there are objective facts about reality.

Let us examine the foregoing in respect of African divinatory systems and see if we could foreground in African divinatory systems such elements as 'criticism', 'reflexion', 'logic' and 'written philosophical tradition' that are constantly hammered on by professional philosophers in denigrating ethnophilosophy. The last point has been taken care of by the historical development of philosophy. To insist that writing is a precondition for philosophy is to say, among others, that the philosophical persuasions that endured from Thales to, say, Plotinus do not constitute 'philosophy' because those Ancient figures did not document their thoughts. This point has been over-flogged in the field of African philosophy by most scholars who disagree with an insistence on writing as a precondition for doing philosophy. This is not to say however that the art of writing is completely out of place in African divinatory systems, especially those involving the use of objects or paraphernalia in the process of divination.

\footnotetext{
88|kuenobe, “Logical Positivism,” p. 480.

89 Barry Hallen, A Short History of African philosophy (Bloomington: Indiana University Press, 2002), p. 11.

90 Rettová, “The Role of African Languages in African Philosophy,” p. 135.

91 See Polycarp Ikuenobe, “The Parochial Universalist Conception of 'Philosophy' and 'African Philosophy'," Philosophy East and West Vol. 47, No. 2 (1997), p. 201.

92 Ikuenobe, “Logical Positivism, Analytic Method, and Criticisms of Ethnophilosophy,” p. 486.

93 Kwame Anthony Appiah, Necessary Questions: An Introduction to Philosophy (Englewood Cliffs, N.J.: Prentice Hall, 1989), p. 211.

94 Ikuenobe, “Logical Positivism,” p. 486.
} 
In other words, if hieroglyphs, pictography, logography-and all such symbolic categories-are regarded as constituting writing, then Ifá graphemes, the outcome of the cast of $o \square p e \square l e \square$ in Ifá divination, for instance, cannot be ruled out as forms of writing which could only be read or interpreted by those socialized or trained in the system. The point here is simple: if a professional philosopher (a literate observer) visits an African diviner (say, an Ifá diviner) with the understanding that the latter is not literate, then he is likely to be stunned by the time the diviner reads or interprets the signature or "writing" that is revealed after the process of divination. Put another way, our untrained observer will struggle vainly to make any meaning of the vertical markings of Ifá graphemes among the Yorùbá or, among the Senegambians, the kaleidoscopic images that result from cowrie shell divination, ${ }^{95}$ or the reading of entrails among the Me'en, an ethnic group of southwestern Ethiopia. 96

Thus, Adeleke Adeeko says of Ifá system that "[t]o the untrained observer, the link between palm-nut manipulation (or string casting) and readable, visible imprints are thoroughly occultic."97 Knut Graw's description of the principles that are involved in Senegambian cowrie shell divination further shows that, like Yorùbá Ifá, Senegambian cowrie shell divination "rests upon a technical basis that can be learned and acquired."98 According to Graw:

Each count is followed by interpretations, instructions, sometimes questions, soliciting the client's response to the messages of the cast shells. The diviner pronounces what he sees, moves on in his interpretation, elaborates upon specific points, and responds to the reactions of his or her client by recasting the cowries for further detailing. Even gesture, every word forms yet another element in the diviner's search for the nature and development of the client's predicament. 99

Aside the issue concerning writing, the other three elements-criticism, reflexion and logic-are interrelated. Because of their revelatory and symbolic modes of arriving at truth African divinatory systems are sometimes seen as lacking these elements. Elsewhere, I have used Ifá divinatory system to show that Yorùbá diviners "often come together in seminar-like gatherings to exchange view on ese Ifá and ensure that the ẹse Ifá are intact as historical material."100 These gatherings initiate a disposition for criticism and reflection and serve as avenues for a diviner to exchange useful ideas with "better informed colleagues on various subjects beyond his knowledge."101

\footnotetext{
95 See Graw, “Beyond Expertise: Reflections on Specialist Agency and the Autonomy of the Divinatory Ritual," pp. 92-109.

96 See Abbink, “Reading the Entrails: Analysis of an African Divination Discourse,” pp. 705-726.

97 Adeleke Adeeko, “"Writing” and "Reference” in Ifá," in Ifá Divination, Knowledge, Power, and Performance, edited by Jacob K. Olupona and Rowland Abiodun (Bloomington: Indiana University Press, 2016), p. 70.

98 Graw, “Beyond Expertise: Reflections on Specialist Agency and the Autonomy of the Divinatory Ritual,” p. 94.

99 Ibid.

100 Adegbindin, Ifá, p. 183.

101 Wande Abimbola, "The Literature of the Ifá Cult," in Sources of Yorùbá History, edited by Saburi O. Biobaku (Oxford Clarendon Press, 1973), p. 48.
} 
This no doubt attests to the ratiocination of African diviners which, unfortunately, is questioned when "philosophy" is understood through the lens of logical positivism that reduces philosophy to science or the analytic tradition that stipulates that "the nature and method of philosophy involve conceptual and critical analysis." 102 This further suggests that, in arriving at truth during divination, the African diviner does not rely only on the revelatory mode but sometimes-in revealing the culprit of a murder, for instance-employs the analytical mode in place of the revelatory mode. This, according to J.P. Kiernan, means that we can have a sharp shifting "from the revelatory mode to a more analytical one, from hidden knowledge to visibly unspoken or cryptic knowledge, and, finally to knowledge articulated in clear intelligence speech." 103 In light of this, Kiernan adds, "the analytical discourse can assume primacy over the revelatory and symbolic modes." 104

As a result of their mythical or religious colouration, African divinatory systems, like all other legitimate candidates of ethnophilosophy, may not be easily amenable to logical thinking in the Aristotelian sense. History has it that, in an attempt to correct the Greek intellect which itself was undisciplined and chaotic during his time, Aristotle founded logic. 105 This historical fact is, perhaps, the stimulant behind Western dogmatic intellectualism that sees logic as a virtual sinecure of Western philosophy. The fact is that, in impartial terms, the indigenous African intellect is logical. If, following Will Durant, logic is the "art and method of correct thinking,"106 and thinking is a natural attribute of man, then M. Akin Makinde is right to contend that there are no "systems of human thought anywhere in the world in which the principles of logic (noncontradiction, identity, and excluded middle) are never employed in reasoning, either consciously or unconsciously." 107 Makinde adds that "these fundamental principles of logic need not be learned by, or taught to, people before they could reason logically," 108 thereby dissolving the critical and negative use of ethnophilosophy.

The inference here is that even if we grant that African divinatory systems be categorized under a people's religious conceptions, we should not forget that "the circumstances of men's lives do much to determine their philosophy." 109 This, in turn, empowers the view that philosophy cannot be completely distanced from a people's inherited religious conceptions.

\footnotetext{
102 Ikuenobe, “Logical Positivism,” p. 482.

103 J.P. Kiernan, "The Truth Revealed or the Truth Assembled: Reconsidering the Role of the African Diviner in Religion and Society," Journal for the Study of Religion Vol. 8, No. 2 (1995), p. 15.

104 Ibid., p. 16.

105 Will Durant, The Story of Philosophy (New York: Simon and Schuster Inc., 1961), p. 47.

106 Ibid., p. 48.

107 M. Akin Makinde, African Philosophy: The Demise of a Controversy (lle-lfe: Obafemi Awolowo University Press, 2007), p. 42.

108 Ibid.

${ }^{109}$ Bertrand Russell, History of Western Philosophy (London: Routledge, 1996), p. 14.
} 


\section{CONCLUSION}

In Africa, African divinatory systems elicit, among others, a high level of scepticism on the part of the clients who often test the diviner's mnemonic ingenuity and his ability to decipher the causes of and solutions to the problems brought before him. This is one of the reasons why, in most cases, clients go from one diviner to another in ways that reflect a questioning of the objectivity of the divining process. This point shows that "the diviner's dominance is neither absolute nor exclusive." 110 To maintain his credibility before his clients, therefore, a diviner often makes sure that his clients are not dissatisfied with his divinatory process.

In respect of the foregoing, J.P. Kiernan explicates that:

...diviners are particularly attentive to the nuances of their clients'... solutions and to the complexities of the social symptoms, in order to produce a measure of fit between what the belief system allows and what the clients perceive to be their needs. Consequently, specialist and client enter into a protracted process of negotiation in order to establish within the parameters of shared beliefs a truth that is both palatable and actionable. ${ }^{111}$

Outside of Africa, African diviners do not enjoy the form of respect their people accord them at home. It is true, as J.P. Kiernan observes, that "they are commonly regarded as weavers of spells, purveyors of superstition and agent of sinister forces." 112 Expectedly, too, African divination-because of its oral nature-has been dragged into the rationality debate whereby it is contended that anonymous corpus of writings, including such practices as African divination, should be discarded as subterfuge or irrational.

But the rationality debate is stale as we now have volumes of published materials that reveal the irrational nature of that line of thought in the first place. Insistent champions of literacy, with strong fervor for hegemonic science, have also used the notion of non-normal mode of cognition to undermine what Knut Myhre phrases as "two prevalent aspects of African divination: popular participation in séances and transcultural divination." 113 Myhre argues that the best way to appreciate African divination as a form of inquiry is to "account for the epistemic relationship between diviner and client." 114

The position Myhre is pushing is aptly rendered by Philip M. Peek, a foremost scholar of African divination, who contends that:

With our emphasis on divination as a system of knowledge in action, we are reminded that our scientific tradition is but one way of knowing and that we can gain much from other systems proven effective over the centuries. African divination systems involve a combination of (as we commonly label cognitive processes) "logical-analytical" and "intuitive-synthetically" modes of thinking, while in the European tradition the separation of these modes is rigidly maintained. ${ }^{115}$

\footnotetext{
110 Kiernan, "The Truth Revealed or the Truth Assembled: Reconsidering the Role of the African Diviner in Religion and Society," p. 10.

111 Ibid., p. 11.

112 Ibid., p. 3.

113 Knut Christian Myhre, "Divination and Experience: Explorations of a Chagga Epistemology," The Journal of the Royal Anthropological Institute Vol. 12, No. 2 (2006), p. 315.

114 Ibid.

115 Philip M. Peek, “Introduction: The Study of Divination, Present and Past," in African Divination Systems, edited by Philip M. Peek (Bloomington: Indiana University Press, 1991), p. 3.
} 